\title{
Development and characterization of novel microsatellite markers for Arion slug species
}

\author{
Miriam A. Zemanova $\cdot$ Eva Knop $\cdot$ Gerald Heckel
}

Received: 27 November 2014/ Accepted: 12 December 2014/Published online: 18 December 2014

(C) Springer Science+Business Media Dordrecht 2014

\begin{abstract}
Seventeen polymorphic microsatellite markers were isolated and characterized in Arion vulgaris/lusitanicus, which belongs to the worst European slug pests with serious economic and ecological impact. These markers were tested on 23 individuals collected in a population in Switzerland. Numbers of alleles ranged from 2 to 14 per locus, observed and expected heterozygosities ranged from 0.174 to 0.87 , and from 0.162 to 0.903 , respectively. These loci were also successfully amplified and were polymorphic in the closely related species A. rufus and A. ater. These loci represent the first highly polymorphic nuclear markers described for A. vulgaris and pave the way for population genetics and molecular ecology research of the important Arion pest slugs.
\end{abstract}

Keywords Arion vulgaris - Arion lusitanicus $\cdot$ Arion rufus · Arion ater 454 Pyrosequencing · Invasive species · Mollusks

One of the major threats to global biodiversity is the invasion by alien species. The slug Arion vulgaris (syn. Arion lusitanicus) belongs to the hundred most invasive species in Europe (DAISIE 2009). It causes significant

M. A. Zemanova ( ()$\cdot$ G. Heckel

Computational and Molecular Population Genetics, Institute of Ecology and Evolution, University of Bern, Baltzerstrasse 6, 3012 Bern, Switzerland

e-mail: miriam.zemanova@iee.unibe.ch

M. A. Zemanova · E. Knop

Community Ecology, Institute of Ecology and Evolution,

University of Bern, Baltzerstrasse 6, 3012 Bern, Switzerland

G. Heckel

Swiss Institute of Bioinformatics, Genopode, 1015 Lausanne, Switzerland economic losses in agriculture and horticulture, and it might lead to a decline of native related species, probably by competition or hybridization (Proschwitz 1997). Here, we report on the development of 17 microsatellite markers for A. vulgaris and related slugs, that can be applied e.g. in population genetics analyses of the invasion history or tests of hybridization with related species.

Genomic DNA was extracted from one individual of $A$. vulgaris sampled in Gruyères, Switzerland (N 46 $34^{\prime}$, W $7^{\circ} 2^{\prime}$ ) in 2012 using the standard phenol-chloroform extraction protocol. We sheared seven hundred nanograms of DNA by nebulization and used DNA fragments in the length range between 600 and 900 bp for Next-Generation Sequencing. Library preparation and sequencing were done following the manuals for the GS Junior pyrosequencing system FLX Titanium (454 Life Sciences Corp). After initial filtering of sequence reads that failed the Key Pass Filter of the system because they did not start with the sequence expected from library preparation, we retained 110,975 raw sequencing reads of $388 \mathrm{bp}$ average length. These reads were searched for di-, tri-, and tetranucleotide microsatellite motifs of at least 10 repeat units length using MSATCOMMANDER version 0.8.2 for Windows (Faircloth 2008). PCR primers were designed using PRIMER3 release 1.1.1 (Rozen and Skaletsky 2000), implemented in MSATCOMMANDER, using the default parameters without any tagging options. We tested 103 primers on polyacrylamid gels and assessed their polymorphism and amplification strength. We selected 17 primer pairs that successfully amplified products of the expected size based on the length of the sequence from which the primers were designed, and that exhibited polymorphism. These were tested on 23 individuals collected at a single locality near Blumenstein, Switzerland (N $46^{\circ} 44^{\prime}$, W $7^{\circ} 31^{\prime}$ ). We used PCR reaction volumes of $10 \mu \mathrm{l}$, including $5 \mu \mathrm{l}$ of the 
Table 1 Microsatellite loci for A. vulgaris tested in 23 individuals from a Swiss population

\begin{tabular}{|c|c|c|c|c|c|c|c|}
\hline Locus & $\begin{array}{l}\text { GenBank accession } \\
\text { number }\end{array}$ & Repeat motif & $\begin{array}{l}\text { Primer sequences } \\
\left(5^{\prime}-3^{\prime}\right)\end{array}$ & $\begin{array}{l}\text { Size range } \\
\text { (bp) }\end{array}$ & $\mathrm{N}_{\mathrm{A}}$ & $\mathrm{H}_{\mathrm{O}}$ & $\mathrm{H}_{\mathrm{E}}$ \\
\hline ALU_02_3 & KP247477 & ATC & $\begin{array}{l}\text { F: CGAGTTCCATTTCTCCCGTG } \\
\text { R: TGGATGGCCTGACTTCGTG }\end{array}$ & $301-343$ & 9 & 0.682 & 0.797 \\
\hline ALU_06_4 & KP247478 & AATC & $\begin{array}{l}\text { F: ATAACGCGGTCCGAACTGG } \\
\text { R: CAACTCATTGGCCGACCTC }\end{array}$ & $280-356$ & 6 & 0.391 & $0.729 *$ \\
\hline ALU_11_2 & KP247479 & AG & $\begin{array}{l}\text { F: GCCTTAAACTCCAGAGGCGT } \\
\text { R: GTCAAGATAACAAGGCACAAACT }\end{array}$ & $103-117$ & 8 & 0.714 & 0.823 \\
\hline ALU_12_2 & KP247480 & AG & $\begin{array}{l}\text { F: ACAGAAGTGAGATTCAGGAGGT } \\
\text { R: CGTACTTTGTTGCCTGATTGT }\end{array}$ & $109-120$ & 5 & 0.826 & 0.880 \\
\hline ALU_13_2 & KP247481 & AG & $\begin{array}{l}\text { F: ATACCAGAGGGCAAACGGG } \\
\text { R: ACAGGCACAAACTTAGAAGTCG }\end{array}$ & $237-251$ & 7 & 0.696 & 0.799 \\
\hline ALU_30_2 & KP247482 & AG & $\begin{array}{l}\text { F: TGGGAAACATCAATGGGAAACG } \\
\text { R: GCAGCCAGCATAAGACTACC }\end{array}$ & $187-227$ & 4 & 0.652 & $0.903 *$ \\
\hline ALU_34_2 & KP247483 & AG & $\begin{array}{l}\text { F: TATTGGCTCCAGTGCTCCC } \\
\text { R: ACTGATGGTTCCTGTAGCTCG }\end{array}$ & $305-321$ & 5 & 0.478 & 0.662 \\
\hline ALU_37_2 & KP247484 & AG & $\begin{array}{l}\text { F: TGCTGTGTATTTGTTACTGCCC } \\
\text { R: CGTGTCTGCAAGGTTTCCC }\end{array}$ & $230-259$ & 4 & 0.652 & $0.805^{*}$ \\
\hline ALU_60_2 & KP247485 & AT & $\begin{array}{l}\text { F: GCATCTATTTCATTTGGTGTTCCC } \\
\text { R: GTATCATGGGAGATCTAAATATCAAGG }\end{array}$ & $211-223$ & 7 & 0.609 & 0.673 \\
\hline ALU_76_2 & KP247486 & AT & $\begin{array}{l}\text { F: GATCTGCCTGCTCATTCCAC } \\
\text { R: ATGCAGGAGAACGTGCTTG }\end{array}$ & $140-150$ & 6 & 0.696 & 0.715 \\
\hline ALU_79_2 & KP247487 & AT & $\begin{array}{l}\text { F: TGGTATCTTAGTCCATTTCTTGATG } \\
\text { R: TCAGTGCTGTTCAATATGTCTTC }\end{array}$ & $226-244$ & 6 & 0.870 & 0.763 \\
\hline ALU_86_2 & KP247488 & AG & $\begin{array}{l}\text { F: TGGGTGTTCTTGATCCCAC } \\
\text { R: ACGCCAGCTCTGGACATC }\end{array}$ & $277-280$ & 2 & 0.565 & 0.689 \\
\hline ALU_88_2 & KP247489 & $\mathrm{AC}$ & $\begin{array}{l}\text { F: ACCGCGAAGGTGATGACAG } \\
\text { R: ACTGCTGGACGTGATGAAAC }\end{array}$ & 298-309 & 8 & 0.652 & 0.809 \\
\hline ALU_92_2 & KP247490 & AG & $\begin{array}{l}\text { F: GCTACCCAAAGTACCAAGTGC } \\
\text { R: CGGACATGGAATGGGCTTC }\end{array}$ & $332-346$ & 8 & 0.609 & 0.620 \\
\hline ALU_94_2 & KP247491 & AT & $\begin{array}{l}\text { F: TGACAATCGCGAAACGGTG } \\
\text { R: AGAACTTAAGATAATCGGCACG }\end{array}$ & $339-357$ & 6 & 0.609 & 0.689 \\
\hline ALU_96_2 & KP247492 & AT & $\begin{array}{l}\text { F: CATGGCACCGAGCTACAAG } \\
\text { R: GATGACGCTCAACAACCCG }\end{array}$ & $367-381$ & 14 & 0.478 & $0.768 *$ \\
\hline ALU_102_2 & KP247493 & AT & $\begin{array}{l}\text { F: GGCCCTATGTAACGTACACC } \\
\text { R: CCAGTGAGTTTGCCTCAGC }\end{array}$ & $439-443$ & 6 & 0.174 & 0.162 \\
\hline
\end{tabular}

$N_{A}$ number of alleles, $H_{O}$ observed heterozygosity, $H_{E}$ expected heterozygosity: asterisks indicate significant $(P<0.05)$ deviations from HWE

Qiagen multiplex kit, $2 \mu$ l of $\mathrm{H}_{2} \mathrm{O}, 1 \mu \mathrm{l}$ of the primer mix, and $2 \mu \mathrm{l}$ of genomic DNA. The temperature profile was as follows: $15 \mathrm{~min}$ initial denaturation at $96{ }^{\circ} \mathrm{C}$, followed by 32 cycles of denaturation at $94{ }^{\circ} \mathrm{C}$ for $30 \mathrm{~s}$, annealing at $57{ }^{\circ} \mathrm{C}$ for $1 \mathrm{~min} 30 \mathrm{~s}$, extension at $72{ }^{\circ} \mathrm{C}$ for $1 \mathrm{~min} 30 \mathrm{~s}$, and the final extension step of $30 \mathrm{~min}$ at $60{ }^{\circ} \mathrm{C}$. The PCR product was diluted with $20 \mu \mathrm{dH}_{2} \mathrm{O}$ and $1.2 \mu \mathrm{l}$ of the diluted product were mixed with $12 \mu \mathrm{l}$ of the internal size standard (GeneScan ${ }^{\mathrm{TM}}-500 \mathrm{LIZ}^{\mathrm{TM}}$, Applied Biosystems) for determining the length of the PCR products. Finally, the amplified fragments were separated on an ABI Prism 3130 Genetic Analyzer and scored with GeneMapper version 3.7 (Applied Biosystems).

The number of alleles per locus $\left(\mathrm{N}_{\mathrm{A}}\right)$, the observed and expected heterozygosity $\left(\mathrm{H}_{\mathrm{O}}\right.$ and $\left.\mathrm{H}_{\mathrm{E}}\right)$ and tests for deviations from Hardy-Weinberg equilibrium (HWE) were calculated using Arlequin 3.5.1.2 (Excoffier and Lischer 2010). The number of alleles ranged from 2 to 14 per locus, observed and expected heterozygosities ranged from 0.174 to 0.87 , and from 0.162 to 0.903 , respectively (Table 1 ). 
Significant departures from HWE were detected for four loci, potentially due to the presence of null alleles. We successfully cross-amplified these loci in the closely related species $A$. rufus ( 3 populations, 72 individuals) and $A$. ater ( 3 populations, 48 individuals). All loci were polymorphic also within these species, with an average number of alleles per locus of 4 for $A$. rufus and 3 for A. ater. These markers will be useful for assessing genetic diversity in native and invasive populations of Arion sp., their population structure and parentage analysis in potential hybrids.

Acknowledgments We thank Susanne Tellenbach for help in the laboratory, and the Next Generation Sequencing Platform and Doreen Becker at the University of Bern, Institute of Genetics, for assistance and access to infrastructure. This project has been supported by the Swiss Federal Office for the Environment (BAFU).

\section{References}

Excoffier L, Lischer HEL (2010) Arlequin suite ver 3.5: a new series of programs to perform population genetics analyses under Linux and Windows. Mol Ecol Resour 10:564-567

Faircloth BC (2008) MSATCOMMANDER: detection of microsatellite repeat arrays and automated, locus-specific primer design. Mol Ecol Resour 8:92-94

DAISIE (2009) Handbook of alien species in Europe. Springer, Dordrecht

Proschwitz TV (1997) Arion lusitanicus Mabille and A. rufus (L.) in Sweden: a comparison of occurrence, spread and naturalization of two alien slug species. Heldia 4:137-138

Rozen S, Skaletsky HJ (2000) Primer3 on the WWW for general users and for biologist programmers. In: Misener S, Krawetz SA (eds) Bioinformatics methods and protocols: methods in molecular biology. Humana Press, Totowa 